\title{
PROPOSAL OF A METHOD TO EVALUATE SAFETY OF THE ROAD TRANSPORT SYSTEMS OPERATION
}

\section{PROPOZYCJA METODY OCENY BEZPIECZEŃSTWA DZIALANIA SYSTEMÓW TRANSPORTU DROGOWEGO}

\author{
Maciej Woropay $^{1}$, Piotr Bojar ${ }^{2}$, Grzegorz Hoppe ${ }^{3}$ \\ $(1,2)$ University of Technology and Life Sciences in Bydgoszcz, \\ Uniwersytet Technologiczno - Przyrodniczy w Bydgoszczy \\ 85 - 789 Bydgoszcz, ul. Kaliskiego 7
}

(3) Remondis Bydgoszcz Ltd

Remondis Bydgoszcz Sp. z.o.o 85-749 Bydgoszcz ul. Inwalidów 4

e-mails: $(1,2)$ kem@utp.edu.pl, (3) grzegorz.hoppe@op.pl

\begin{abstract}
The transport system are sociotechnical systems in which the direct realization of the tasks is dealt with by an executive subsystem consisting of the elementary subsystems of a human - a technical object (an operator - a means of transport) type realizing the tasks within the system environment. In respect of a human located within a transport system the most significant criterion in the evaluation of the transports being realized is their safety.

Due to the complexity of the systems being analysed in the paper, it has been attempted to evaluate the influence of the forcing factors on the safety of this system operation.
\end{abstract}

Key words: transport system, folded system, forcing factors

Streszczenie. Systemy transportowe są systemami socjotechnicznymi, w których bezpośrednią realizacją zadań zajmuje się podsystem wykonawczy złożony $\mathrm{z}$ podsystemów elementarnych typu człowiek - obiekt techniczny (operator - środek transportu) realizujących zadania w otoczeniu systemu. Ze względu na człowieka umiejscowionego w systemie transportowym najistotniejszym kryterium w ocenie realizowanych przewozów jest ich bezpieczeństwo.

Ze względu na złożoność analizowanych systemów w pracy podjęto próbę oceny wpływu oddziaływań czynników wymuszających na bezpieczeństwo działania tego systemu.

Słowa kluczowe: system transportowy, system złożony, czynniki wymuszające 


\section{PROPOSAL OF A METHOD TO EVALUATE SAFETY OF THE ROAD TRANSPORT SYSTEMS OPERATION}

\section{Introduction}

The transport systems are the systems the aim of which is to realize transports over the determined area, using the means of transport. The essential requirements regarding the transport systems are:

- transportation safety,

- means of transport reliability,

- transportation punctuality,

- transportation adequate frequency,

- adequate standard of the services provided.

The transport systems are an example of the sociotechnical systems of a Human - a Technical Object - an Environment $<\mathrm{H}-\mathrm{TO}-\mathrm{E}>$ type in which the direct realization of the system tasks is dealt with by an executive subsystem consisting of the elementary subsystems of a human - a technical object (an operator - a means of transport) type realizing the tasks within the system environment. Moreover, a human within the transport system may be located:

$\circ$ inside the means of transport (a passenger),

$\circ$ within the means of transport environment, other drivers, pedestrians, etc.

In respect of a human located within a transport system the most significant criterion in the evaluation of the transports being realized is safety.

The safety level of the task realization is influenced by the risks resulting from the interaction of the forcing factors, affecting an elementary executive subsystem.

These factors may be divided into [8]:

- working (within a system) - forcing factors affecting a means of transport as a result of realization of the usable functions,

- external - forcing factors being characteristic for interaction of the environment affection a means of transport (not depending on its functioning),

- antropotechnical - forcing factors affecting a means of transport as a result of human actions, e.g. due to an operator's faults. 
The authors of the works regarding safety of the transport systems and safety of a road traffic, e.g.: $[4,5,6,7]$ evaluate the safety level of the road traffic on the basis of the databases provided by the police. These bases include data regarding the number of the road accidents which occurred within the time interval under analysis and number of fatalities and injured people resulting from the accidents occurred.

The essential source document of the accident registration system is a road events card which is filled in by the Police officers at the event site, according to their subjective judgment of the course and accompanying circumstances.

It should be noted that due to lack of diagnostic measures and no time, the state of a vehicle is not evaluated after a road event, therefore the Police reports mostly provide inappropriate driver's actions, such as (overspeeding, driving speed not adjusted to the existing road conditions etc.) as a most frequent cause of a road event.

A road event is a complex phenomenon which may result from the interaction of the aforementioned forcing factors: working (resulting from a vehicle serviceability condition), external (resulting from the environmental interaction) and antropotechnical (being a result of faults of a driver and people located in the system and within its environment).

When analysing the causes of the road accidents occurrence they should be treated as independent events which may occur individually or jointly, as shown in the table No. 1.

Table 1. Possible sequences of events leading to a road accident occurrence.

\begin{tabular}{|c|c|c|c|}
\hline Pos. & $\begin{array}{c}\text { Working factors } \\
\text { interaction }\end{array}$ & $\begin{array}{c}\text { External factors } \\
\text { interaction }\end{array}$ & $\begin{array}{c}\text { Antropotechnical } \\
\text { factors interaction }\end{array}$ \\
\hline 1 & $\mathbf{1}$ & 1 & 1 \\
\hline 2 & $\mathbf{1}$ & 0 & 1 \\
\hline 3 & $\mathbf{1}$ & 1 & 0 \\
\hline 4 & $\mathbf{1}$ & 0 & 0 \\
\hline 5 & 0 & 1 & 1 \\
\hline 6 & 0 & 1 & 0 \\
\hline 7 & 0 & 0 & 1 \\
\hline 8 & 0 & 0 & 0 \\
\hline
\end{tabular}


The table represents sequences of the events leading to the risk states of a transport system safety, where:

1 - an event in which interaction of the chosen forcing factors had an influence on the road event occurrence,

0 - an event in which interaction of the chosen forcing factors had no influence on the road event occurrence.

The risk state of the system safety No. 8 is an abstract state, the occurrence of which was affected by none of the system elements.

\section{Object of the study}

The object of the study is a generally defined transport system being a sociotechnical system of a Human - a Technical Object - an Environment $<H-T O-E>$ type, the main task of which is to transport people safely within the determined quantitative and territorial range, using the means of transport being operated and maintained inside this system.

The system under investigation is included in the class of the complex real systems, performing their tasks in the defined environment $[8,9,10,11]$.

A complex system is such a system which includes sets of elements that can in turn be also complex systems interlinked by their functions and subordinated to the realization of the assigned tasks [12, 15].

An element (an elementary subsystem) is called such a system in which it is impossible to distinguish the subsystems of a lower level [14].

The complexity of a system depends both on the number of its subsystems, located on different decomposition levels, and the number of these levels.

The location of each subsystem in the system structure and its operation aim are to be taken into account when performing investigations of the system. The subsystems located on the successive decomposition levels may be treated as indivisible objects, depending on the problem consideration circumstantiality.

The features of the system as a whole are determined not only on the basis of the features of its individual subsystems, but also on the basis of its structure.

An example of such a transport system type is a collective urban transport system. The transportation inside an urban transport system may be 
performed using different means of transport. The most popular, however, is a bus transport system.

The following subsystems may be distinguished on the individual decomposition levels (Fig.1):

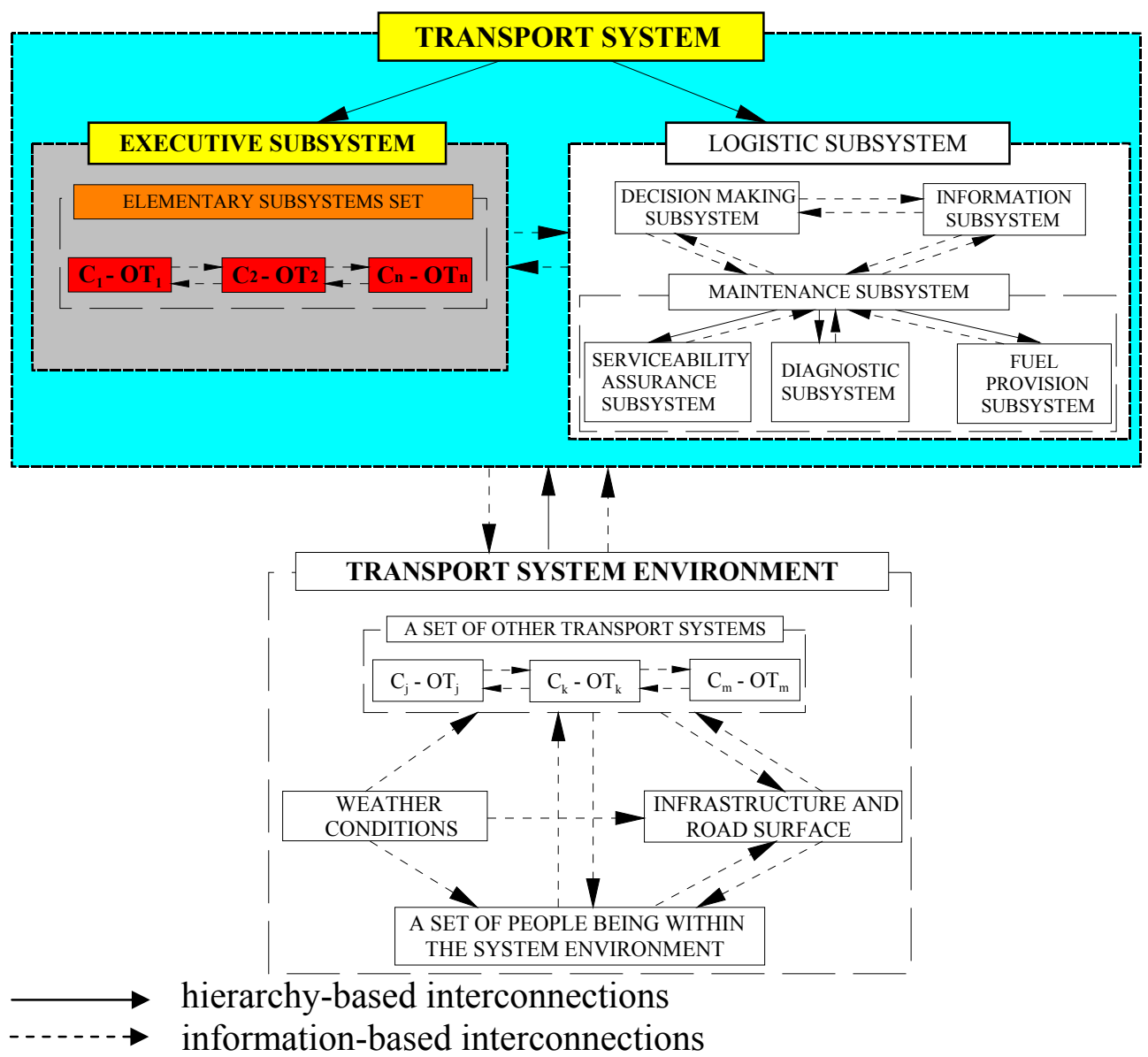

Figure 1. Means of transport operation and maintenance system model.

As it results from the above diagram, a human inside a transport system under analysis may be located inside the system (a bus driver or a passenger), as well as he/she may be located within the system environment (other vehicle drivers, bikers, pedestrians). 
Due to differentiated location of a human and his/her safety, there is a need to build a method which would comprehensively include the forcing factors affecting this system safety operation.

\section{Aim of the study}

The aim of the study is to build an algorithm to evaluate the forcing factors affecting the road transport system operation safety .

\section{Algorithm to evaluate transport system operation safety}

The algorithm presented in the figure 2 reflects the operational procedure used when evaluating the road transport operation safety, taking into account the major forcing factors described herein.

Three essential members A, B and C may be distinguished in this algorithm, they are related to :

A - evaluation of the means of transport operation safety,

$\mathrm{B}$ - evaluation of the interaction of the system environment affecting the operation safety of that system,

$\mathrm{C}$ - evaluation of the interaction of the humans located inside the system and within its environment affecting the operation safety of that system.

The individual members of the algorithm may form separate algorithms to evaluate interaction of the forcing factors affecting the operation safety of the system under analysis. When combined they constitute a comprehensive evaluation of the transport system operation safety.

In terms of the algorithm complexity the individual blocks have been presented in a simplified form using a symbolic description, all the symbols have been explained in the table 2 . 


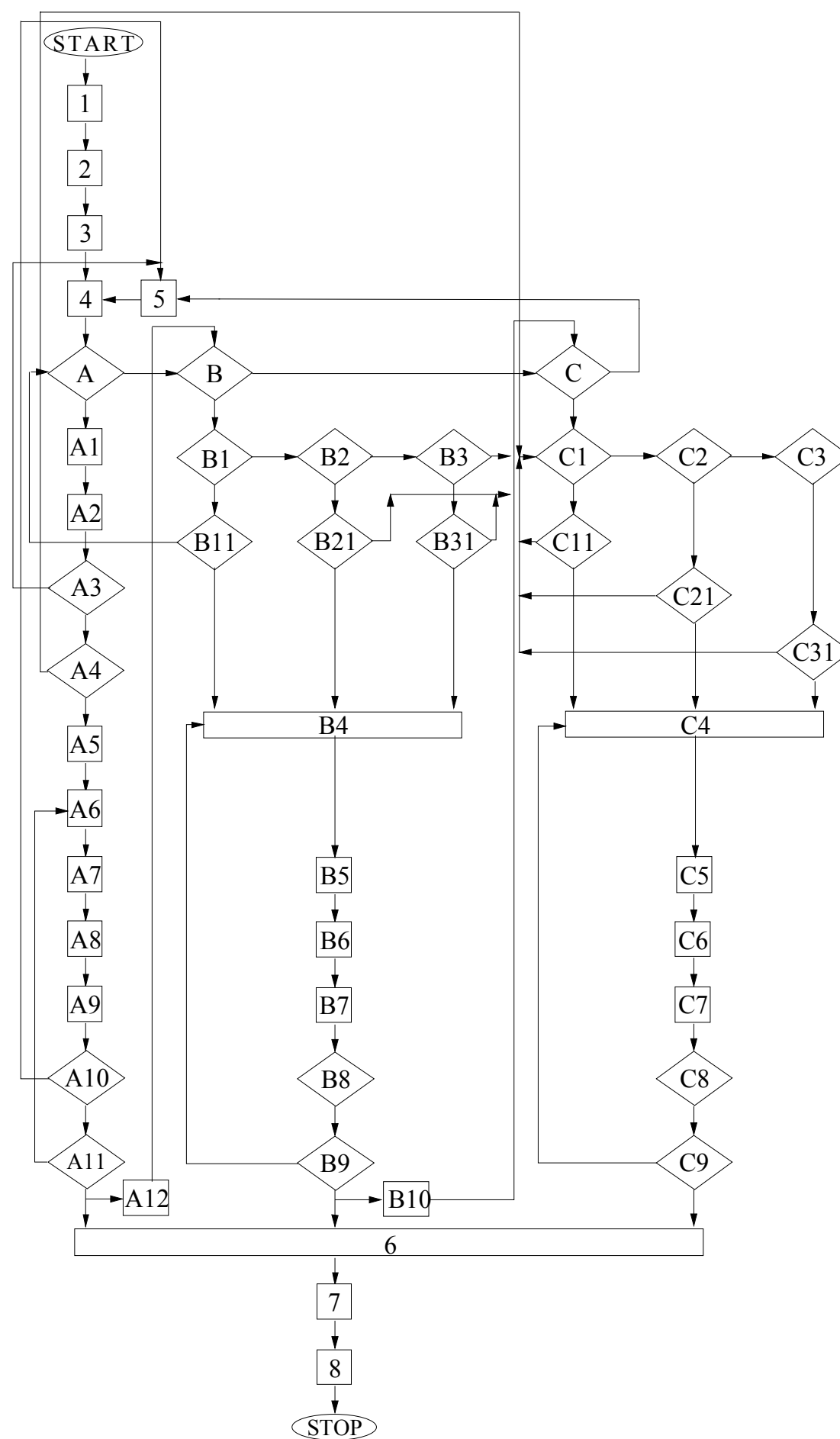

Fig. 2 Algorithm to evaluate the transport system operation safety. 
Table 2. Description of the algorithm to evaluate the transport system operation safety

\begin{tabular}{|c|c|}
\hline Block code & Code description \\
\hline 1 & $\begin{array}{l}\text { Determine a set of the road events occurred within the } \\
\text { analysed time interval } \mathrm{Zi} ; \mathrm{i}=\{1,2,3, \ldots, \mathrm{k}\} \text {. }\end{array}$ \\
\hline 2 & $\begin{array}{l}\text { Select the events being significant from the point of view } \\
\text { of the system operation safety being analysed. }\end{array}$ \\
\hline 3 & $\begin{array}{l}\text { Arrange in series the events according to their occurrence } \\
\text { date } Z_{1}, Z_{2}, Z_{3}, \ldots, Z_{\mathrm{k}} \text {. }\end{array}$ \\
\hline 4 & Select the first event to be evaluated $Z_{i}, i=1$. \\
\hline 5 & Select another toad event to be analysed $Z_{i}+1$. \\
\hline 6 & $\begin{array}{l}\text { Make collective evaluation of the transport system } \\
\text { operation safety }\end{array}$ \\
\hline 7 & Evaluate the costs due to the events occurred \\
\hline 8 & Show the result \\
\hline A & $\begin{array}{l}\text { Did a damage to a subsystem of a means of transport cause } \\
\text { the occurrence of the event under analysis? }\end{array}$ \\
\hline A1 & $\begin{array}{l}\text { Determine the criteria to evaluate the significance of the } \\
\text { damaged subsystem. }\end{array}$ \\
\hline A2 & Evaluate the significance of the damaged subsystem. \\
\hline A3 & $\begin{array}{l}\text { Is the damaged subsystem significant from the point of } \\
\text { view of the means of transport operation safety? }\end{array}$ \\
\hline A4 & $\begin{array}{l}\text { Did the damage to the significant subsystem affected the } \\
\text { improper operator's actions? }\end{array}$ \\
\hline A5 & $\begin{array}{l}\text { Evaluate the change level to the means of transport } \\
\text { serviceability state as a result of the damage to the } \\
\text { analysed subsystem. }\end{array}$ \\
\hline A6 & $\begin{array}{l}\text { Determine a set of indices to evaluate the means of } \\
\text { transport operation safety. }\end{array}$ \\
\hline A7 & $\begin{array}{l}\text { Determine the criteria to evaluate the means of transport } \\
\text { operation safety. }\end{array}$ \\
\hline A8 & $\begin{array}{l}\text { Determine the set of indices being representative for the } \\
\text { evaluation of the means of transport operation safety. }\end{array}$ \\
\hline A9 & Evaluate safety of the means of transport operation. \\
\hline A10 & Is the analysed event $Z_{\mathrm{i}}=\mathrm{Z}_{\mathrm{k}}$ ? where $\mathrm{i}=\{1,2,3, \ldots, \mathrm{k}\}$ \\
\hline
\end{tabular}


Table 2. Description of the algorithm to evaluate the transport system operation safety - continuation.

\begin{tabular}{|c|c|}
\hline Block code & Code description \\
\hline A11 & Is the resultant model adequate? \\
\hline A12 & Check if the event B occurred as well. \\
\hline B & $\begin{array}{l}\text { Did the interactions of the environment cause the } \\
\text { occurrence of the analysed event? }\end{array}$ \\
\hline B1 & $\begin{array}{l}\text { Did the improper state of the pavement surface cause the } \\
\text { occurrence of the analysed event? }\end{array}$ \\
\hline B11 & $\begin{array}{l}\text { Did the improper state of the pavement surface cause a } \\
\text { damage to the means of transport? }\end{array}$ \\
\hline B2 & $\begin{array}{l}\text { Did the improper road infrastructure cause the occurrence } \\
\text { of the event? }\end{array}$ \\
\hline B21 & $\begin{array}{l}\text { Did the improper road infrastructure cause improper } \\
\text { actions of the people located within the system and within } \\
\text { its environment? }\end{array}$ \\
\hline B3 & $\begin{array}{l}\text { Did the weather conditions cause the occurrence of the } \\
\text { event? }\end{array}$ \\
\hline B31 & $\begin{array}{l}\text { Did the weather conditions cause improper actions of the } \\
\text { people located within the system and within its } \\
\text { environment?? }\end{array}$ \\
\hline B4 & $\begin{array}{l}\text { Determine a set of the indices to evaluate safe interaction } \\
\text { of the environment affecting people and means of } \\
\text { transport. }\end{array}$ \\
\hline B5 & $\begin{array}{l}\text { Determine criteria to evaluate safe interaction of the } \\
\text { environment affecting people and means of transport. }\end{array}$ \\
\hline B6 & $\begin{array}{l}\text { Determine a set of the indices representative for evaluation } \\
\text { of the safe interaction of the environment affecting people } \\
\text { and means of transport. }\end{array}$ \\
\hline B7 & $\begin{array}{l}\text { Evaluate safe interaction of the environment affecting } \\
\text { people and means of transport. }\end{array}$ \\
\hline B8 & $\begin{array}{l}\text { Is the analysed event } Z_{i}=Z_{k} \text { ? } \\
\text { where } i=\{1,2,3, \ldots, k\}\end{array}$ \\
\hline B9 & Is the resultant model adequate? \\
\hline $\mathrm{B} 10$ & Check if the event $\mathrm{C}$ occurred as well. \\
\hline
\end{tabular}


Table 2. Description of the algorithm to evaluate the transport system operation safety - continuation.

\begin{tabular}{|c|c|}
\hline Block code & Code description \\
\hline $\mathrm{C}$ & $\begin{array}{l}\text { Did the actions of the people located inside the means of } \\
\text { transport and within its environment cause the occurrence } \\
\text { of the event? }\end{array}$ \\
\hline $\mathrm{C} 1$ & $\begin{array}{l}\text { Did the improper driver's actions cause the occurrence of } \\
\text { the event? }\end{array}$ \\
\hline $\mathrm{C} 11$ & $\begin{array}{l}\text { Did the improper driver's actions cause a damage to the } \\
\text { means of transport subsystem? }\end{array}$ \\
\hline $\mathrm{C} 2$ & $\begin{array}{l}\text { Did the improper actions of the means of transport } \\
\text { passengers cause the occurrence of the event? }\end{array}$ \\
\hline $\mathrm{C} 21$ & $\begin{array}{l}\text { Did the improper actions of the passengers affect the } \\
\text { wrong driver's actions? }\end{array}$ \\
\hline $\mathrm{C} 3$ & $\begin{array}{l}\text { Did the improper actions of the people located within the } \\
\text { environment of the means of transport cause the } \\
\text { occurrence of the event? }\end{array}$ \\
\hline $\mathrm{C} 31$ & $\begin{array}{l}\text { Did the improper actions of the people located within the } \\
\text { environment of the means of transport affect the wrong } \\
\text { driver's actions? }\end{array}$ \\
\hline $\mathrm{C} 4$ & $\begin{array}{l}\text { Determine a set of the indices to evaluate undesirable } \\
\text { interactions of the people located inside the means of } \\
\text { transport and within its environment. }\end{array}$ \\
\hline $\mathrm{C} 5$ & $\begin{array}{l}\text { Determine the evaluation criteria of the safe interactions } \\
\text { of the people located inside the means of transport and } \\
\text { within its environment. }\end{array}$ \\
\hline C6 & $\begin{array}{l}\text { Determine a set of the indices representative for evaluation } \\
\text { of the interactions of the people located inside the means } \\
\text { of transport and within its environment. }\end{array}$ \\
\hline $\mathrm{C} 7$ & $\begin{array}{l}\text { Evaluate safe interaction of the people located inside the } \\
\text { means of transport and within its environment. }\end{array}$ \\
\hline $\mathrm{C} 8$ & Is the analysed event $\mathrm{Zi}=\mathrm{Zk}$ gdzie, $\mathrm{i}=\{1,2, \ldots, \mathrm{k}\}$ \\
\hline C9 & Is the resultant model adequate? \\
\hline
\end{tabular}

\section{Summary}

- The method to analyse safety of the transport system operation safety suggested herein is an innovative approach of the road transport system safety evaluation. 
- The method is an universal one and it may be applied to evaluate operation safety of various types of the road transport systems.

- The components of the algorithm may constitute separate methods to evaluate interactions of the individual forcing factors affecting the safety level of the system operation under analysis.

- There is a necessity to continue further analysis of the problem described herein, in order to show precisely all the relations taking place between the individual elements of the system under analysis.

\section{References}

[1]. Zielińska A.: CARE - Europejska Baza Danych o Wypadkach Drogowych. Bezpieczeństwo Ruchu Drogowego nr 3/2004 - kwartalnik motoryzacyjny Instytutu Transportu Samochodowego Warszawa 2004.

[2]. Guzek M.: Bezpieczeństwo ruchu drogowego w Polsce - stan aktualny, podstawowe charakterystyki. Materiały na VI sympozjum bezpieczeństwa systemów. Kiekrz 1996r. Wydawnictwo Instytutu Technicznego Wojsk Lotniczych.

[3]. Wicher J.: Bezpieczeństwo samochodów $i$ ruchu drogowego. Wydawnictwo Komunikacji i Łączności. Wydanie 2, Warszawa 2004.

[4]. Praca zbiorowa pod redakcją Tomasza Szczuraszka: Bezpieczeństwo ruchu miejskiego. Wydawnictwa Komunikacji i Łączności. Warszawa 2005.

[5] Woropay M.: Metoda oceny realizacji procesu eksploatacji w systemie transportowym. ITE, Bydgoszcz - Radom 1998.

[6] Woropay M., Muślewski Ł.: Jakość w ujęciu systemowym. ITE, Bydgoszcz - Radom 2005.

[7] Woropay M., Knopik L., Landowski B.: Modelowanie procesów eksploatacji $w$ systemie transportowym. ITE, Bydgoszcz - Radom 2001.

[8] Woropay M., Szubartowski M., Migawa K.: Model oceny $i$ ksztaltowania gotowości operacyjnej podsystemu wykonawczego $w$ systemie transportowym. ITE, Bydgoszcz - Radom 2003.

[9] Woropay M.: Metoda budowy wielopoziomowych systemów do badania niezawodności z elementów o wyznaczonej a priori istotności. OPT, Katowice 1981.

[10]Dynarski S.: Elementy teorii systemów i cybernetyki. PWN Warszawa 1979.

[11]Praca zbiorowa pod redakcją G. J. Klira: Ogólna teoria systemów. WNT, Warszawa 1976 


\section{PROPOZYCJA METODY OCENY BEZPIECZEŃSTWA DZIAŁANIA SYSTEMÓW TRANSPORTU DROGOWEGO}

\section{Wprowadzenie}

Systemy transportowe są systemami których celem jest realizacja przewozów po wyznaczonym obszarze, z wykorzystaniem środków transportu. Podstawowymi wymaganiami dotyczącymi systemów transportowych są:

- bezpieczeństwo przewozów,

- niezawodność środków transportu

- terminowość przewozów,

- odpowiednia częstotliwość przewozów,

- odpowiedni standard świadczonych usług.

Systemy transportowe są przykładem systemów socjotechnicznych typu Człowiek - Obiekt Techniczny - Otoczenie $<\mathrm{C}-\mathrm{OT}-\mathrm{O}>$, w których bezpośrednią realizacją zadań systemu zajmuje się podsystem wykonawczy złożony z podsystemów elementarnych typu człowiek - obiekt techniczny (operator - środek transportu) realizujących zadania w otoczeniu systemu. Ponadto człowiek w systemie transportowym może być usytuowany:

- wewnątrz środków transportu (pasażera),

- w otoczeniu środków transportu, inni kierowcy, piesi, itd.

Ze wzgledu na czlowieka umiejscowionego $\mathrm{w}$ systemie transportowym najistotniejszym kryterium $w$ ocenie realizowanych przewozów jest ich bezpieczeństwo.

$\mathrm{Na}$ poziom bezpieczeństwa realizacji zadań wpływają zagrożenia wynikające z oddziaływania czynników wymuszających, oddziałujących na elementarny podsystem wykonawczy.

Czynniki te można podzielić na [8]:

- robocze (w systemie) - czynniki wymuszające oddziałujące na środek transportu w wyniku realizacji funkcji użytecznych,

- zewnętrzne - czynniki wymuszające charakteryzujące oddziaływanie otoczenia na środek transportu (nie uwarunkowane jego funkcjonowaniem),

- antropotechniczne - czynniki wymuszające oddziałujące na środek transportu w wyniku działalności człowieka np. na skutek błędów operatora. 
W pracach dotyczących bezpieczeństwa systemów transportowych i bezpieczeństwa ruchu drogowego np.: $[4,5,6,7]$, autorzy oceniają poziom bezpieczeństwa ruchu drogowego na podstawie policyjnych baz danych. Bazy te zawierają dane dotyczące liczby wypadków drogowych do których doszło $\mathrm{w}$ analizowanym przedziale czasu oraz liczby osób zabitych i rannych w wyniku zaistniałych wypadków.

Podstawowym dokumentem źródłowym systemu ewidencji wypadków jest karta zdarzeń drogowych, którą funkcjonariusze Policji wypełniają na miejscu zdarzenia, według własnej subiektywnej oceny jego przebiegu i okoliczności towarzyszących.

Należy zwrócić uwagę że po zdarzeniu drogowym nie oceniania się stanu technicznego pojazdu z powodu braku środków diagnostycznych oraz braku czasu, dlatego też jako najczęstszą przyczynę zajścia zdarzenia drogowego funkcjonariusze Policji podają niewłaściwe działania kierowcy, np.: (nadmierna prędkość, niedostosowanie prędkości do panujących warunków drogowych, itd.).

Zdarzenie drogowe jest zjawiskiem złożonym i może być skutkiem oddziaływania opisanych powyżej czynników wymuszających: roboczych (wynikajacych ze stanu zdatności pojazdu), zewnętrznych (wynikajacych $z$ oddziatywania otoczenia) $i$ antropotechnicznych (będacych wynikiem błędów kierowcy i ludzi usytuowanych w systemie i jego otoczeniu).

Analizując przyczyny powstawania wypadków drogowych należy je traktować jako zdarzenia niezależne, mogace występować pojedynczo lub tqcznie, co przedstawiono w tabeli $\mathrm{nr} 1$.

Tabela 1. Możliwe sekwencje zdarzeń prowadzące do zaistnienia wypadku drogowego.

\begin{tabular}{|c|c|c|c|}
\hline Lp. & $\begin{array}{c}\text { Oddziaływanie } \\
\text { czynników } \\
\text { roboczych }\end{array}$ & $\begin{array}{c}\text { Oddziaływanie } \\
\text { czynników } \\
\text { zewnętrznych }\end{array}$ & $\begin{array}{c}\text { Oddziaływanie } \\
\text { czynników } \\
\text { antropotechnicznych }\end{array}$ \\
\hline 1 & $\mathbf{1}$ & 1 & 1 \\
\hline 2 & $\mathbf{1}$ & 0 & 1 \\
\hline 3 & $\mathbf{1}$ & 1 & 0 \\
\hline 4 & $\mathbf{1}$ & 0 & 0 \\
\hline 5 & 0 & 1 & 1 \\
\hline 6 & 0 & 1 & 0 \\
\hline 7 & 0 & 0 & 1 \\
\hline 8 & 0 & 0 & 0 \\
\hline
\end{tabular}


W tabeli 1 odwzorowano sekwencje zdarzeń prowadzących do stanów zagrożenia bezpieczeństwa systemu transportowego, przy czym:

1 - zdarzenie polegające na tym, że oddziaływanie wybranych czynników wymuszających miało wpływ na zajście zdarzenia drogowego,

0 - zdarzenie polegające na tym, że oddziaływanie wybranych czynników wymuszających miało wpływu na zajście zdarzenia drogowego.

Stan zagrożenia bezpieczeństwa systemu nr. 8 jest stanem abstrakcyjnym na powstanie którego nie miał wpływu żaden z elementów systemu.

\section{Obiekt badań}

Obiektem badań jest ogólnie pojęty system transportowy, będący systemem socjotechnicznym typy Człowiek - Obiekt Techniczny - Otoczenie $<C-O T$ - $O>$, którego głównym zadaniem jest bezpieczne przemieszczanie ludzi w wyznaczonym zakresie ilościowym i terytorialnym, za pomocą środków transportu eksploatowanych w tym systemie.

Badany system jest zaliczany do klasy złożonych systemów rzeczywistych, realizującym zadania $\mathrm{w}$ określonym otoczeniu $[8,9,10,11]$.

System zlożony to system, zawierający zbiory elementów, które z kolei moga być także zlożonymi systemami, powiqzanymi funkcjonalnie ze sobq i podporzqdkowane realizacji wyznaczonych zadań $[12,15]$.

Elementem (podsystemem elementarnym), nazywa się taki podsystem, w którym nie da się wyodrębnić podsystemów niższego rzędu [14].

O złożoności systemu decyduje zarówno liczba jego podsystemów, usytuowanych na różnych poziomach dekompozycji, jak i liczba tych poziomów.

W trakcie badań systemu należy uwzględnić usytuowanie każdego podsystemu w jego strukturze i cel jego działania. Podsystemy usytuowane na kolejnych poziomach dekompozycji można traktować jako obiekty niepodzielne, w zależności od szczegółowości rozpatrywania problemu. Cechy systemu jako całości określa się nie tylko na podstawie cech jego poszczególnych podsystemów, ale również na podstawie jego struktury.

Przykładem takiego typu systemu transportowego jest zbiorowy transport miejski. W transporcie miejskim przewozy moga być realizowane z wykorzystaniem różnych środków transportu. Najpopularniejszym jest jednak system komunikacji autobusowej 
W systemie miejskiej komunikacji autobusowej, na poszczególnych poziomach dekompozycji można wyróżnić następujące podsystemy (rys.1):

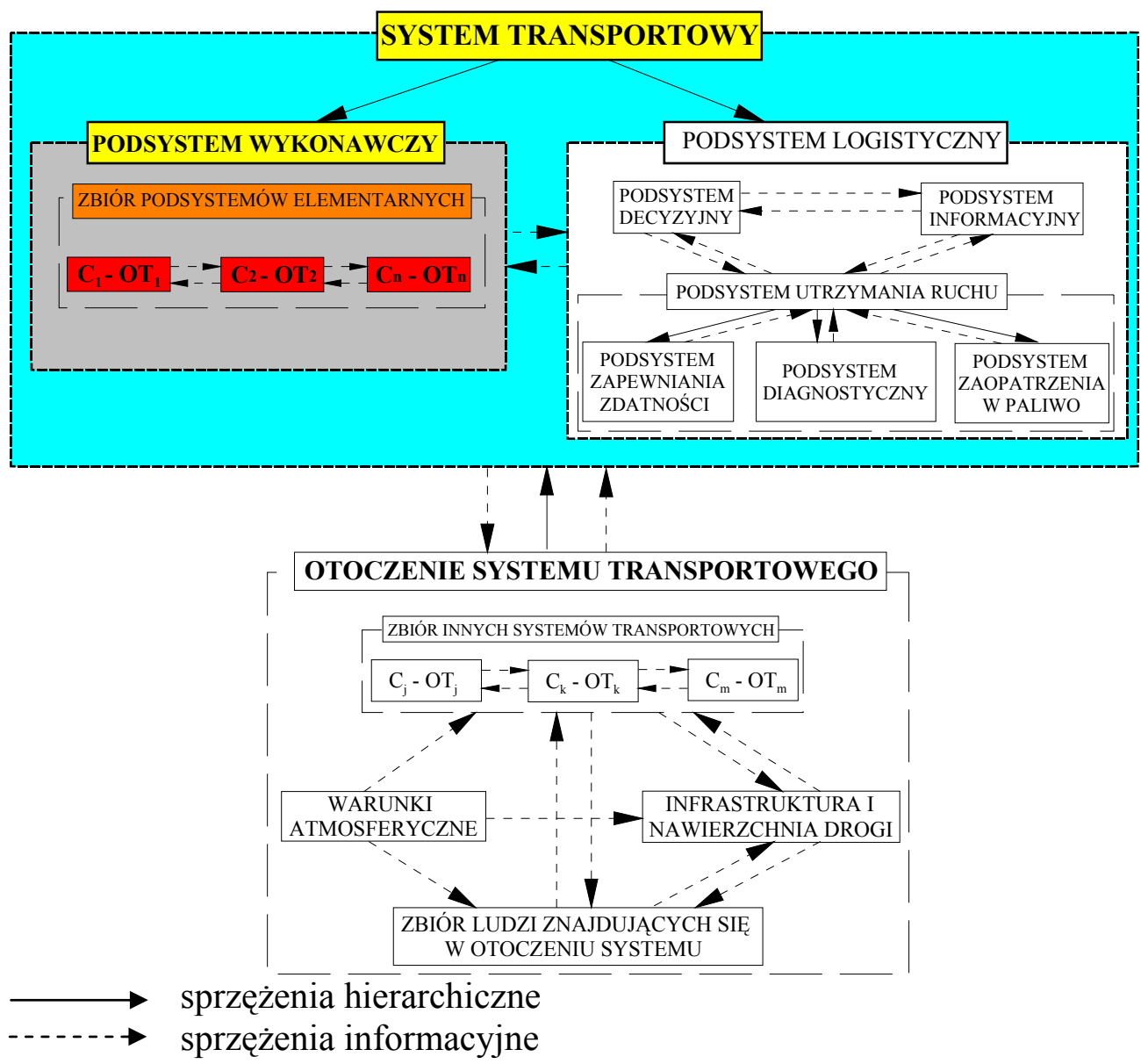

Rysunek 1. Model systemu eksploatacji środków transportu.

$\mathrm{Z}$ powyższego rysunku wynika że człowiek $\mathrm{w}$ analizowanym systemie transportowym może być usytuowany wewnątrz tego systemu (kierowca autobusu lub pasażer), jak również może być usytuowany w otoczeniu systemu (kierujący innymi pojazdami, rowerzyści, piesi).

Ze względu na zróżnicowane usytuowanie człowieka i jego bezpieczeństwo istnieje potrzeba budowy metody która w sposób kompleksowy uwzględni oddziaływanie czynników wymuszających na bezpieczeństwo działania tego systemu. 


\section{Cel pracy}

Celem pracy jest budowa algorytmu oceny oddziaływań czynników wymuszających na bezpieczeństwo działania systemu transportu drogowego.

\section{Algorytm oceny bezpieczeństwa dzialania systemu transportowego}

Algorytm przedstawiony na rysunku 2 odzwierciedla procedurę postępowania podczas oceny bezpieczeństwa działania systemu transportu drogowego $\mathrm{z}$ uwzględnieniem głównych czynników wymuszających opisanych w pracy.

W algorytmie tym wyróżnić można trzy zasadnicze człony A, B i C dotyczące kolejno:

A - oceny bezpieczeństwa działania środków transportu,

B - oceny oddziaływania otoczenia systemu na bezpieczeństwo działania tego systemu,

$\mathrm{C}$ - oceny oddziaływania ludzi usytuowanych w systemie $\mathrm{i}$ jego otoczeniu na bezpieczeństwo działania tego systemu.

Poszczególne człony algorytmu mogą stanowić odrębne algorytmy oceny oddziaływania czynników wymuszających na bezpieczeństwo działania analizowanego systemu. Razem stanowią kompleksową ocenę bezpieczeństwa działania systemu transportowego.

Ze względu na złożoność algorytmu poszczególne bloki przedstawiono w sposób skrótowy $\mathrm{z}$ opisem symbolicznym, wszystkie symbole zostały opisane w tabeli 2. 


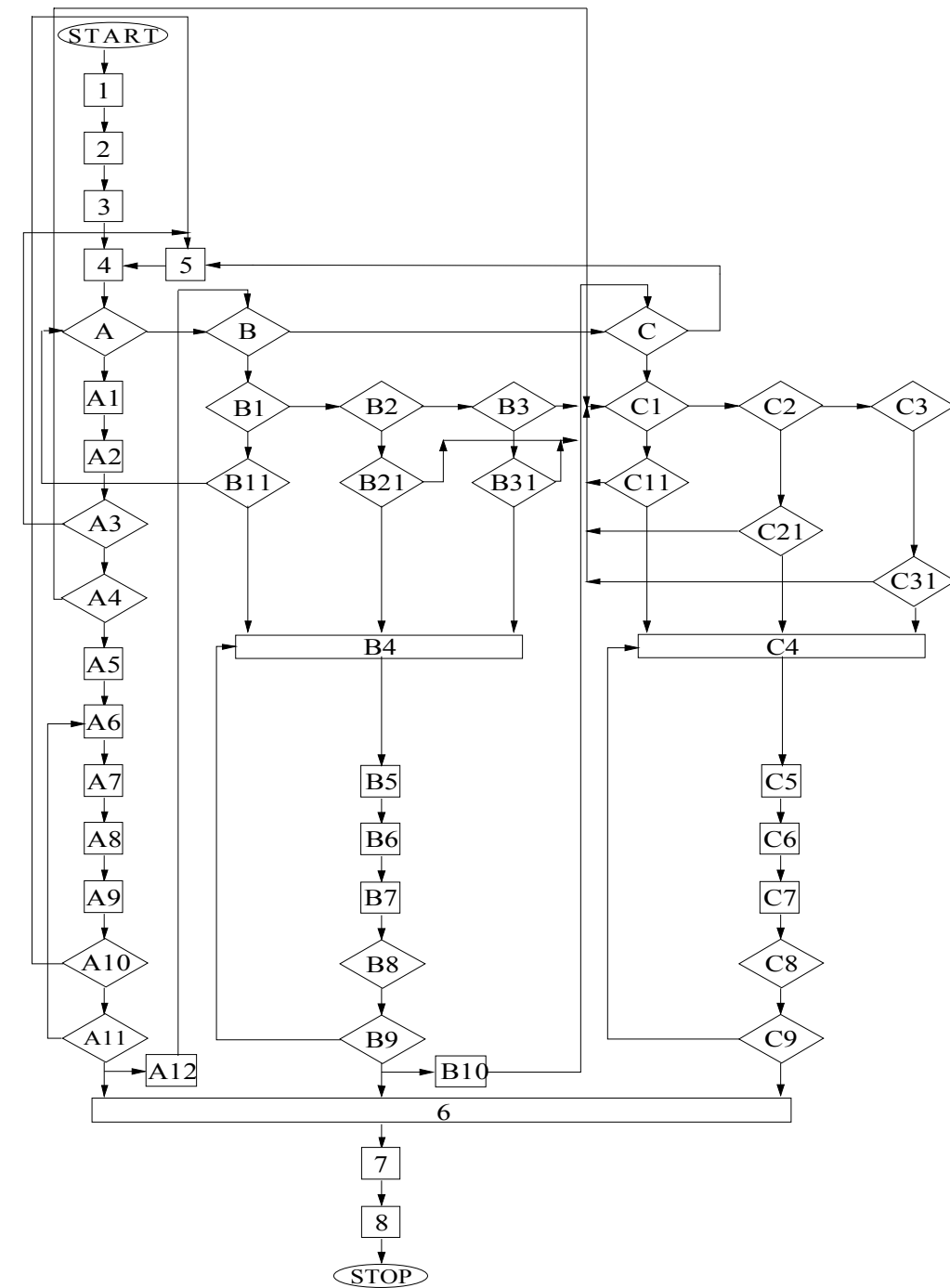

Rys. 2 Algorytm oceny bezpieczeństwa działania systemu transportowego.

Tabela 2. Opis algorytmu oceny bezpieczeństwa działania systemu transportowego.

\begin{tabular}{|c|l|}
\hline Kod bloku & \multicolumn{1}{|c|}{ Opis kodu } \\
\hline 1 & $\begin{array}{l}\text { Wyznacz zbiór zdarzeń drogowych zaistniałych } \mathrm{w} \text { analizowanym } \\
\text { przedziale czasu } \mathrm{Zi} ; \mathrm{i}=\{1,2,3, \ldots, \mathrm{k}\} .\end{array}$ \\
\hline 2 & $\begin{array}{l}\text { Wybierz zdarzenia istotne } \mathrm{z} \text { punktu widzenia bezpieczeństwa } \\
\text { działania analizowanego systemu. }\end{array}$ \\
\hline 3 & Uszereguj zdarzenia według daty zajścia $\mathrm{Z}_{1}, \mathrm{Z}_{2}, \mathrm{Z}_{3}, \ldots, \mathrm{Z}_{\mathrm{k}}$. \\
\hline 4 & Wybierz do oceny pierwsze zdarzenie $\mathrm{Z}_{\mathrm{i}}, \mathrm{i}=1$. \\
\hline 5 & Wybierz do oceny kolejne zdarzenie drogowe $\mathrm{Z}_{\mathrm{i}}+1$. \\
\hline
\end{tabular}


Tabela 2. Opis algorytmu oceny bezpieczeństwa działania systemu transportowego - cd.

\begin{tabular}{|c|c|}
\hline Kod bloku & Opis kodu \\
\hline 6 & $\begin{array}{l}\text { Dokonaj zbiorczej oceny bezpieczeństwa działania systemu } \\
\text { Transportowego }\end{array}$ \\
\hline 7 & Dokonaj oceny kosztów na skutek zaistniałych zdarzeń \\
\hline 8 & Pokaż wynik \\
\hline A & $\begin{array}{l}\text { Czy przyczyna zajścia analizowanego zdarzenia było uszkodzenie } \\
\text { podsystemu środka transportu? }\end{array}$ \\
\hline A1 & Ustal kryteria oceny istotności uszkodzonego podsystemu. \\
\hline A2 & Dokonaj oceny istotności uszkodzonego podsystemu. \\
\hline A3 & $\begin{array}{l}\text { Czy uszkodzony podsystem jest istotny } \mathrm{z} \text { punktu widzenia } \\
\text { bezpieczeństwa działania środka transportu? }\end{array}$ \\
\hline A4 & $\begin{array}{l}\text { Czy uszkodzenie podsystemu istotnego miało wpływ na } \\
\text { niewłaściwe działania operatora? }\end{array}$ \\
\hline A5 & $\begin{array}{l}\text { Oceń poziom zmian stanu zdatności środka transportu jako skutku } \\
\text { uszkodzenia analizowanego podsystemu. }\end{array}$ \\
\hline A6 & $\begin{array}{l}\text { Wyznacz zbiór wskaźników do oceny bezpieczeństwa działania } \\
\text { środka transportu. }\end{array}$ \\
\hline A7 & Ustal kryteria oceny bezpieczeństwa działania środka transportu. \\
\hline A8 & $\begin{array}{l}\text { Wyznacz zbiór wskaźników reprezentatywnych do oceny } \\
\text { bezpieczeństwa działania środka transportu. }\end{array}$ \\
\hline A9 & Dokonaj oceny bezpieczeństwa działania środka transportu. \\
\hline A10 & $\begin{array}{l}\text { Czy analizowane zdarzenie } Z_{i}=Z_{k} \text { ? } \\
\text { gdzie } \mathrm{i}=\{1,2,3, \ldots, \mathrm{k}\}\end{array}$ \\
\hline A11 & Czy model wynikowy jest adekwatny? \\
\hline $\mathrm{A} 12$ & Sprawdź czy również zaszło zdarzenie B. \\
\hline B & $\begin{array}{l}\text { Czy przyczyną zajścia analizowanego } \\
\text { oddziaływanie otoczenia? }\end{array}$ \\
\hline B1 & $\begin{array}{l}\text { Czy przyczyna zajścia analizowanego zdarzenia był niewłaściwy } \\
\text { stan nawierzchni jezdni? }\end{array}$ \\
\hline B11 & $\begin{array}{l}\text { Czy niewłaściwy stan nawierzchni jezdni był przyczyną } \\
\text { uszkodzenia środka transportu? }\end{array}$ \\
\hline B2 & $\begin{array}{l}\text { Czy przyczyną zajścia zdarzenia była niewłaściwa infrastruktura } \\
\text { drogi? }\end{array}$ \\
\hline B21 & $\begin{array}{l}\text { Czy niewłaściwa infrastruktura drogi była przyczyna } \\
\text { niewłaściwych działań ludzi usytuowanych w systemie i jego } \\
\text { otoczeniu? }\end{array}$ \\
\hline B3 & $\begin{array}{l}\text { Czy przyczyną zajścia zdarzenia było oddziaływanie czynników } \\
\text { atmosferycznych? }\end{array}$ \\
\hline
\end{tabular}


Proposal of a method to evaluate safety.....

Tabela 2. Opis algorytmu oceny bezpieczeństwa działania systemu transportowego $-\mathrm{cd}$.

\begin{tabular}{|c|c|}
\hline Kod bloku & Opis kodu \\
\hline B31 & $\begin{array}{l}\text { Czy oddziaływanie czynników atmosferycznych było przyczyną } \\
\text { niewłaściwych działań ludzi usytuowanych w systemie i jego } \\
\text { otoczeniu? }\end{array}$ \\
\hline B4 & $\begin{array}{l}\text { Wyznacz zbiór wskaźników do oceny bezpiecznego } \\
\text { oddziaływania otoczenia na ludzi i środki transportu. }\end{array}$ \\
\hline B5 & $\begin{array}{l}\text { Ustal kryteria oceny bezpiecznego oddziaływania otoczenia } \\
\text { na ludzi i środki transportu. }\end{array}$ \\
\hline B6 & $\begin{array}{l}\text { Wyznacz zbiór wskaźników reprezentatywnych do } \\
\text { bezpiecznego oddziaływania otoczenia na ludzi i środki } \\
\text { transportu. }\end{array}$ \\
\hline B7 & $\begin{array}{l}\text { Dokonaj oceny bezpiecznego oddziaływania otoczenia na ludzi i } \\
\text { środki transportu. }\end{array}$ \\
\hline B8 & $\begin{array}{l}\text { Czy analizowane zdarzenie } Z_{\mathrm{i}}=Z_{\mathrm{k}} \text { ? } \\
\text { gdzie } \mathrm{i}=\{1,2,3, \ldots, \mathrm{k}\}\end{array}$ \\
\hline B9 & Czy model wynikowy jest adekwatny? \\
\hline $\mathrm{B} 10$ & Sprawdź czy również zaszło zdarzenie C. \\
\hline $\mathrm{C}$ & $\begin{array}{l}\text { Czy przyczyna zajścia analizowanego } \text { zdarzenia } \text { było } \\
\text { oddziaływanie ludzi usytuowanych w środku transportu i jego } \\
\text { otoczeniu? }\end{array}$ \\
\hline $\mathrm{C} 1$ & $\begin{array}{l}\text { Czy przyczyną zajścia zdarzenia były niewłaściwe działania } \\
\text { kierowcy? }\end{array}$ \\
\hline $\mathrm{C} 11$ & $\begin{array}{l}\text { Czy niewłaściwe działania kierowcy były przyczyną uszkodzenia } \\
\text { podsystemu środka transportu? }\end{array}$ \\
\hline $\mathrm{C} 2$ & $\begin{array}{l}\text { Czy przyczyną zajścia zdarzenia były niewłaściwe działania } \\
\text { pasażerów środka transportu? }\end{array}$ \\
\hline $\mathrm{C} 21$ & $\begin{array}{l}\text { Czy niewłaściwe działania pasażerów miały wpływ na } \\
\text { błędne działania kierowcy? }\end{array}$ \\
\hline C3 & $\begin{array}{l}\text { Czy przyczyną zajścia zdarzenia były niewłaściwe działania } \\
\text { ludzi usytuowanych w otoczeniu środka transportu? }\end{array}$ \\
\hline $\mathrm{C} 31$ & $\begin{array}{l}\text { Czy niewłaściwe działania ludzi usytuowanych w otoczeniu } \\
\text { środka transportu miały wpływ na błędne działania kierowcy? }\end{array}$ \\
\hline $\mathrm{C} 4$ & 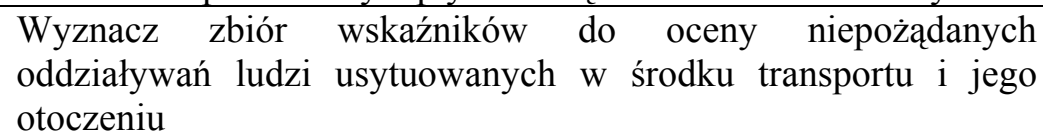 \\
\hline $\mathrm{C} 5$ & $\begin{array}{l}\text { Ustal kryteria oceny bezpiecznych oddziaływań } \\
\text { usytuowanych w środku transportu i jego otoczeniu. }\end{array}$ \\
\hline C6 & $\begin{array}{l}\text { Wybierz zbiór wskaźników reprezentatywnych do oceny } \\
\text { oddziaływań ludzi usytuowanych w środku transportu i jego } \\
\text { otoczeniu. }\end{array}$ \\
\hline
\end{tabular}


Tabela 2. Opis algorytmu oceny bezpieczeństwa działania systemu transportowego - cd.

\begin{tabular}{|c|l|}
\hline Kod bloku & \multicolumn{1}{|c|}{ Opis kodu } \\
\hline $\mathrm{C} 7$ & $\begin{array}{l}\text { Dokonaj oceny bezpiecznego oddziaływania ludzi usytuowanych } \\
\text { w środku transportu i jego otoczeniu. }\end{array}$ \\
\hline $\mathrm{C} 8$ & Czy analizowane zdarzenie $\mathrm{Zi}=\mathrm{Zk}$ gdzie, $\mathrm{i}=\{1,2, \ldots, \mathrm{k}\}$ \\
\hline $\mathrm{C} 9$ & Czy model wynikowy jest adekwatny? \\
\hline
\end{tabular}

\section{Podsumowanie}

a. Zaproponowany $\mathrm{w}$ pracy sposób analizy bezpieczeństwa działania systemu transportowego stanowi innowacyjne podejście oceny bezpieczeństwa systemów transportu drogowego.

b. Metoda jest uniwersalna i może służyć do oceny bezpieczeństwa działania różnego typu systemów transportu drogowego.

c. Składowe części algorytmu mogą stanowić odrębne metody oceny oddziaływania poszczególnych czynników wymuszających na poziom bezpieczeństwa działania analizowanego systemu.

d. Istnieje konieczność dalszej analizy podjętego w pracy problemu w celu dokładnego ukazania wszystkich zachodzących relacji pomiędzy poszczególnymi elementami analizowanego systemu.

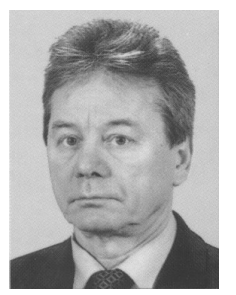

Prof. dr hab. inż. Maciej Woropay jest kierownikiem Katedry Eksploatacji Maszyn Wydziału Mechanicznego Uniwersytetu Technologiczno - Przyrodniczego w Bydgoszczy. W pracy naukowej zajmuje się problemami dotyczącymi teorii systemów, teorii niezawodności i bezpieczeństwa oraz sterowania procesami eksploatacji w złożonych systemach biotechnicznych, a w szczególności sterowaniem tymi procesami w systemach transportu miejskiego. Jest autorem i współautorem ponad 140 prac naukowych, promotorem ponad 150 prac magisterskich i inżynierskich oraz prac doktorskich.

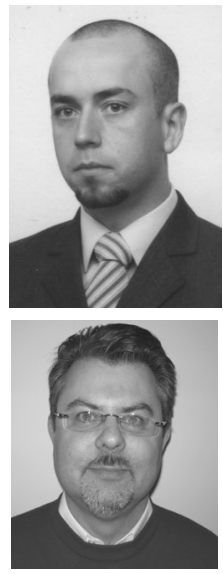

Mgr inż. Piotr Bojar, doktorant w Katedrze Eksploatacji Maszyn Uniwersytetu Technologiczno - Przyrodniczego w Bydgoszczy. W pracy naukowej zajmuje się analizą i oceną bezpieczeństwa działania rzeczywistych systemów transportu drogowego. Autor i współautor kilkunastu publikacji naukowych $\mathrm{z}$ zakresu bezpieczeństwa ruchu drogowego oraz bezpieczeństwa i niezawodności obiektów technicznych.

MSc Grzegorz Hoppe, The President Of The Board Remondis Bydgoszcz Ltd.. The company sees about the complex waste management. The candidate for a doctor's degree of Economic Academy in Poznań 